\title{
Feeding ecology of Pachyurus bonariensis Steindachner, 1879 (Sciaenidae: Perciformes) in the Ibicuí River, Southern Brazil: ontogenetic, seasonal and spatial variations
}

\author{
Lima, DO. ${ }^{\text {a* }}$ and Behr, ER. ${ }^{\mathrm{b} *}$ \\ ${ }^{a}$ Universidade Federal da Fronteira Sul - UFFS, Campus de Cerro Largo, \\ Rua João Sebastiany, 16, CP 63, CEP 97900-000, Cerro Largo, RS, Brazil \\ bUnidade Descentralizada de Educação Superior, Universidade Federal de Santa Maria - UFSM, \\ Rua Francisco Guerino, 407, CEP 98300-000, Silveira Martins, RS, Brazil \\ *e-mail: daniela.ol.lima@gmail.com, everton_behr@hotmail.com
}

Received February 11, 2009 - Accepted April 24, 2009 - Distributed August 31, 2010

(With 3 figures)

\begin{abstract}
Knowledge of the feeding ecology of fish is essential for understanding the functioning of freshwater communities. Here we report on an analysis of the diet of Pachyurus bonariensis Steindachner, 1879, a freshwater sciaenid. Fish were collected bimonthly from December 1999 to January 2002 at three locations along the Ibicuí River in the Rio Grande do Sul State, Brazil. At each location, the specimens were collected in both lentic and lotic environments. The stomachs of 324 fish were analysed for contents and fullness. The main items were Ephemeroptera, Diptera (larvae), Trichoptera and Odonata. Annelida, plant matter, Decapoda, Diptera (pupae), Coleoptera and Mollusca were present in small amounts. The fish consumed smaller amounts of food in winter than in other seasons. The most important source of dietary variation for $P$. bonariensis was the ontogenetic, related to intrinsic biological characters. However, spatial variation was also found, suggesting that this species can adapt its diet to environmental changes. Although $P$. bonariensis showed ontogenetic and spatial variations in the main items consumed, the main items were always insects, characterising $P$. bonariensis as a fish with an insectivorous feeding habit in the Ibicuí River.
\end{abstract}

Keywords: feeding activity, diet composition, trophic ecology, insects, fishes.

\section{Ecologia trófica de Pachyurus bonariensis Steindachner, 1879 (Sciaenidae: Perciformes) no Rio Ibicuí, sul do Brasil: variações ontogenéticas, sazonais e espaciais}

\begin{abstract}
Resumo
A ecologia alimentar de uma espécie é muito importante para o entendimento do funcionamento das comunidades de água doce. Neste trabalho analisamos a dieta de Pachyurus bonariensis, um sciaenídeo restrito a ambientes dulceaquícolas. Os peixes foram coletados bimestralmente de dezembro de 1999 a janeiro de 2002 em três locais do rio Ibicuí no Estado do Rio Grande do Sul, Brasil. Em cada local os espécimes foram coletados em ambiente lótico e lêntico. Estômagos de 324 indivíduos foram analisados quanto ao seu conteúdo e grau de repleção. Os principais itens foram Ephemeroptera, Diptera (larva), Trichoptera e Odonata. Os itens Anellida, matéria vegetal, Decapoda, Diptera (pupas), Coleoptera e Mollusca estiveram presentes em menor quantidade. No inverno os peixes consumiram menor quantidade de alimento, quando comparado com as demais estações. A principal fonte de variação na dieta desse sciaenídeo foi proveniente de mudanças ontogenéticas, relacionadas a fatores biológicos intrínsecos. Entretanto também foi observada variação espacial na dieta de $P$. bonariensis, sugerindo que essa espécie pode adaptar sua dieta a mudanças ambientais. Apesar de $P$. bonariensis apresentar mudanças ontogenéticas e espaciais na sua dieta, os principais itens foram sempre insetos, caracterizando essa espécie como um peixe com hábitos insetívoros no rio Ibicuí.
\end{abstract}

Palavras-chave: atividade alimentar, composição da dieta, ecologia trófica, insetos, peixes. 


\section{Introduction}

Knowledge of the feeding ecology of a species is basic biological knowledge and may allow inferences regarding its population dynamics. This biological knowledge is fundamentally important for the evaluation of fish communities and the conservation of the entire freshwater ecosystem (Fugi and Hahn, 1991). It is necessary to know the trophic spectrum and the feeding activity of the species in its natural habitat, to attain success in conservation efforts. Knowledge of autoecology and of the ecological role of fish populations is mainly derived from diet studies based on analyses of stomach contents (Windell and Bowen, 1978).

The feeding ecology of Neotropical fishes varies widely. The most common differences are ontogenetic, seasonal and spatial, and are reported for a large number of species (Aranha et al., 2000; Lucena et al., 2000; Abelha et al., 2001; Mazzoni and Rezende, 2003; Araújo et al., 2005; Barreto and Aranha, 2006; Rezende and Mazzoni, 2006; Viana et al., 2006; Fugi et al., 2007; Pacheco et al., 2008). The two last sources of variations, seasonal and spatial, are primarily related to changes in food resource composition and availability, which are associated with productivity variations and physicochemical changes in aquatic ecosystems. On the other hand the ontogenetic variations are usually related to morphological changes that lead to shifts in prey selection and capture (Abelha et al., 2001; Vitule and Aranha, 2002; Araújo et al., 2005; Rezende and Mazzoni, 2006; Fugi et al., 2007).

The family Sciaenidae, with approximately 287 species and 78 genera, includes mostly marine fishes and some genera with a secondary adaptation to estuarine and freshwater environments (Casatti, 2003). Among these genera, six are restricted to freshwater and four, Pachyurus, Pachypops, Plagioscion and Petilipinnis, are endemic to South America (Casatti, 2003). The food items most often consumed by members of this family are benthic animals such as crustaceans, polychaetes, mollusks, insects and small fish, and sometimes algae (Mourão and Torres, 1984; Lunardon, 1990; Vazzoler, 1991; Hahn et al., 1997; Figueiredo and Vieira, 1998; Vendel and Chaves, 1998; Hahn et al., 1999; Soares and Vazzoler, 2001; Alvim and Peret, 2004; Branco et al., 2005; Bennemann et al., 2006; Fugi et al., 2007; Pacheco et al., 2008). The sciaenid Pachyurus bonariensis occurs naturally in the rivers of the Paraná-Paraguay-Uruguay system, downstream from the Itaipu Reservoir, including Argentina, Brazil, Paraguay and Uruguay (Casatti, 2001) The P. bonariensis diet was studied once, in two lakes (locally called bays) of the Pantanal, where it had a diet composed mainly of Chironomidae and Ephemeroptera, with important ontogenetic shifts (Fugi et al., 2007). However, an older and not empirical study pointed out that the food of this species was composed of aquatic plants and organic substances from the mud (Devincenzi and Teague, 1942).

The aim of this study was to study the trophic ecology of $P$. bonariensis in the Ibicuí River, where it is one of the dominant species (Behr, 2005). For this, the dietary composition and the feeding activity were studied, and its ontogenetic, seasonal and spatial variations. The dietary composition was analysed to investigate, in Ibicuí River, its insectivorous specialised diet (Fugi et al., 2007). The ontogenetic, seasonal and spatial variations in trophic spectrum were also investigated to confirm its specialised diet at different situations and to analyse what is the mainly source of dietary variations, those principally due to food availability, seasonal and spatial, or the ontogenetic variation. Its feeding activity was analysed to investigate the influence of year seasons and spatial heterogeneity on food ingestion.

\section{Material and Methods}

This study was carried out at three locations along the Ibicuí River, one of the main tributaries of the Uruguay River. The Ibicuí basin is nearly flat, and the river flows slowly over a mainly sandy bed. It is located within the Pampas biome in the State of Rio Grande do Sul, Southern Brazil. Rambo (1994) described the Ibicuí as a shallow river, with broad floodplains and surrounded by swamps and gallery forests. The sampling locations were: in the beginning stretch of the river, near the confluence of the Ibicuí-Mirim and Santa Maria rivers ( $29^{\circ} 47^{\prime} \mathrm{S}$ and $54^{\circ} 56^{\prime} \mathrm{W}$ ); in the intermediate stretch $\left(29^{\circ} 33^{\prime} \mathrm{S}\right.$ and $\left.55^{\circ} 37^{\prime} \mathrm{W}\right)$ and near the mouth of the river $\left(29^{\circ} 25^{\prime} \mathrm{S}\right.$ and $\left.56^{\circ} 38^{\prime} \mathrm{W}\right)$ (Figure 1). At each point, two different environments were sampled: the main channel (lotic - LO), and in the nearby channels or lagoons (lentic - LE) that are connected to the main channel for most of the year.

The collections were carried out every two months at each location, from December 1999 to January 2002. Ten-metre-long gill nets with 1.5, 2.0, 2.5 and $3.0 \mathrm{~cm}$ meshes (measured between adjacent knots) were used. For mesh sizes of 4.0, 5.0, 6.0, 8.0 and $10.0 \mathrm{~cm}$ and for trammel nets $4.0 / 20,5.0 / 20 \mathrm{~cm}$ and $6.0 / 20,20 \mathrm{~m}$ of net were used. The nets were set out for 24 hours in each environment, and were checked every six hours (6:00 AM; 12:00 PM; 6:00 PM and 12:00 AM). In the seasonal analyses, the sampling years were analysed together, and the months were combined according to the seasons: spring (October, November, December), summer (January, February, March), autumn (April, May, June), and winter (July, August, September).

For the diet analysis of $P$. bonariensis, ten individuals from each sample (each net in each hour) were randomly selected, for a total of 324 individuals analysed of the total 602 captured. Voucher specimens were deposited in the Museu de Ciências e Tecnologia, Pontifícia Universidade Católica do Rio Grande do Sul, Porto Alegre, Brazil: MCP26675 and MCP28419. The total standard lengths of theses fishes ranged from 11.4-24.9 (17.3 \pm 2.6$) \mathrm{cm}$ and the total weight from 8.2-199 $(63.5 \pm 31.7) \mathrm{g}$. For the ontogenetic analysis the individuals were separated in four length classes based on its standard lengths. Length class 1 : 


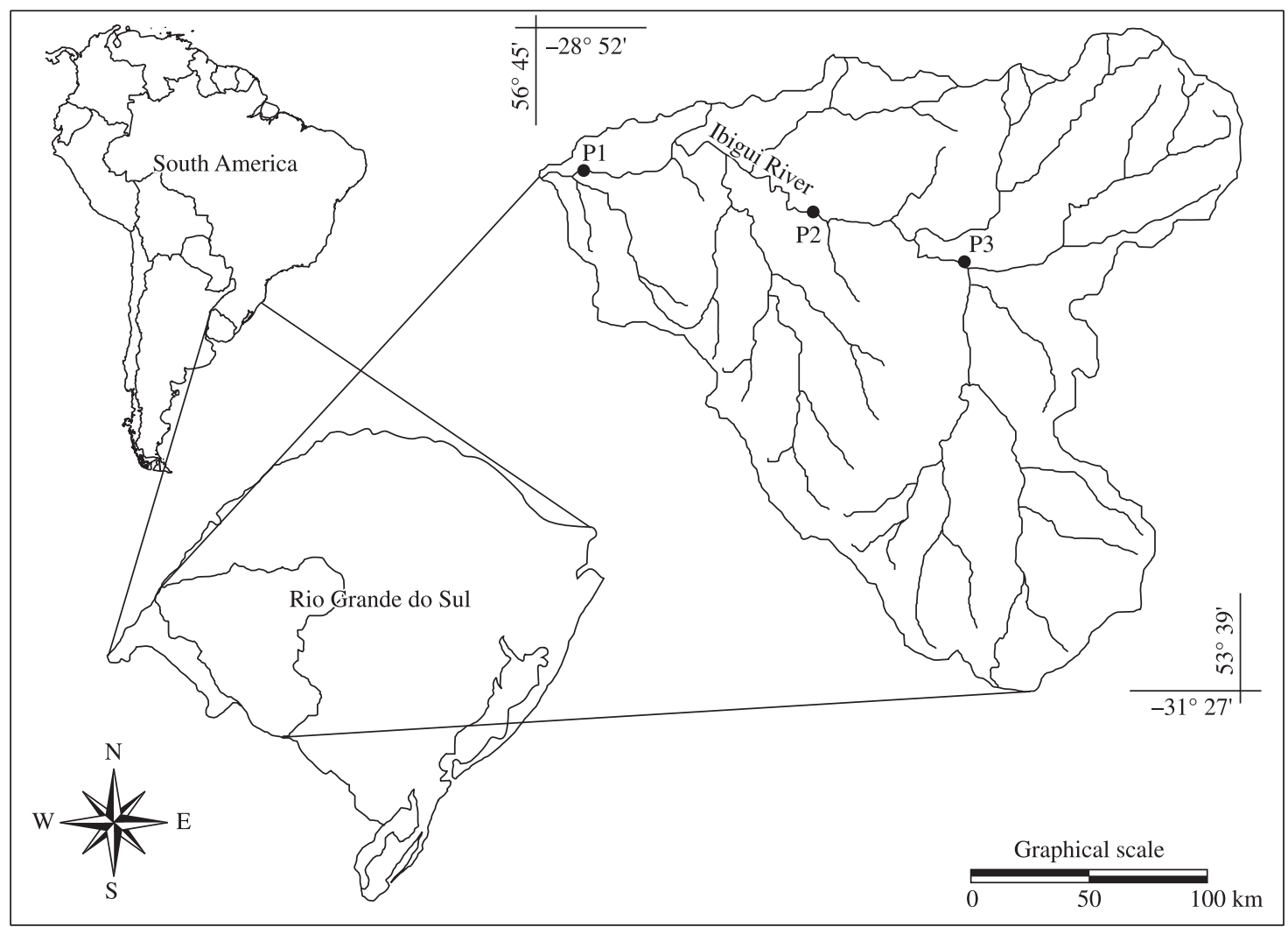

Figure 1. Location of the collection points on the Ibicuí River and its location in the State of Rio Grande do Sul and in South America.

11.4-14.3 cm; length class 2: $14.4-17.3 \mathrm{~cm}$; length class 3: $17.4-20.3 \mathrm{~cm}$ and length class $4: 20.4-24.9 \mathrm{~cm}$.

For each individual, a stomach fullness degree (FD) was assigned to investigate the feeding activity of the species. The FD represents how full the stomach was, and these were divided into the following classes: 0 (empty), 1 (up to 30\%), 2 (between 30 and 70\%) and 3 (over 70\%). The feeding activity was compared between seasons by the Kruskal-Wallis Test, followed by Dunn's Multiple Comparisons Test. Feeding activity was also compared between lentic and lotic environments, for this, the fullness degree for each these environmental was submitted to the Mann-Whitney Test. Kruskal-Wallis and Mann-Whitney tests were run using the GraphPad Instat program.

The stomachs analysed had their food items identified and quantified (to the level of order) by the volumetric method according to Albrecht and Pellegrini-Caramaschi (2003). The volume measurement and the frequency of occurrence were analysed using the Alimentary Index (IAi) proposed by Kawakami and Vazzoler (1980). Food items in an advanced state of digestion were classified as (organic matter-digested O.M.-digested). The items that represented less than 1 in the Alimentary Index (IAi) were combined under the term "Diverse" in the graphs and analyses. Larvae and pupae of Diptera were counted separately because they have different ecologies.
The IAi of each fish group was submitted to a similarity analysis through the Bray-Curtis coefficient, using the statistical program Past. These fish groups were set according to its length class, year seasons and environment (lotic or lentic), generating 36 possible groups. However some possible groups did have any fish captured. Just the mainly items were considered in the development of the cluster analysis. This cluster analysis has the purpose to determine the main important source of variation to $P$. bonariensis diet. In other words, to determine the factor, ontogenetic, seasonal or spatial one, that will most separate the groups.

\section{Results}

The overall median of fullness degree was 2 (lower quartile $=1$; upper quartile $=3$ ). There were significant differences in feeding activity among seasons $(\mathrm{kW}=14.41 ; \mathrm{p}<0.01)$ (Table 1$)$ but not among lentic and lotic environments $(\mathrm{U}=11983.50 ; \mathrm{p}=0.19)$ (Table 2). Dunn's Multiple Comparisons Test indicated significant differences $(p<0.05)$ in feeding activity between winter and all the other seasons (see Table 1).

Pachyurus bonariensis showed a relatively wide trophic spectrum, composed mainly of insects. Juvenile forms of Ephemeroptera, Diptera-larvae, Odonata and Trichoptera were the predominant items (Figure 2). Crustaceans, mollusks, 
Table 1. Fullness degree values for Pachyurus bonariensis in each season in the Ibicuí River ( $\mathrm{N}=$ number of fish analyzed; FD = median fullness degree; $\mathrm{LQ}=$ lower quartile; $\mathrm{UQ}=$ upper quartile; * significant difference between winter and all other seasons).

\begin{tabular}{ccccc}
\hline Season & N & FD & LQ & UQ \\
\hline Summer & 135 & 2 & 1 & 3 \\
Autumn & 60 & 2 & 2 & 3 \\
Winter & 52 & $2 *$ & 1 & 2 \\
Spring & 70 & 3 & 2 & 3 \\
\hline
\end{tabular}

Table 2. Fullness degree values for Pachyurus bonariensis in lotic and lentic environments in the Ibicuí River ( $\mathrm{N}=$ number of fish analysed; FD = median fullness degree; LQ = lower quartile; $\mathrm{UQ}=$ upper quartile; $\mathrm{LE}=$ lentic environment; $\mathrm{LO}=$ lotic environment).

\begin{tabular}{ccccc}
\hline Environment & N & FD & LQ & UQ \\
\hline LE & 151 & 2 & 1 & 3 \\
LO & 166 & 2 & 1 & 3 \\
\hline
\end{tabular}

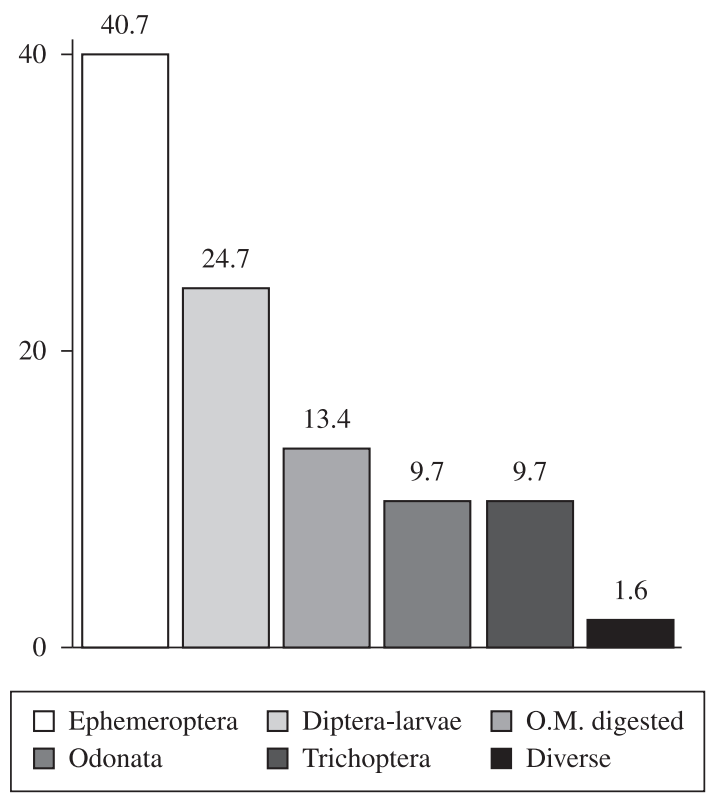

Figure 2. Feeding index (IAi) of Pachyurus bonariensis in the IbicuíRiver.Theitem (organicmatter-digestedO.M.-digested) refers to invertebrates that were in an advanced state of decomposition. The item "diverse" includes unidentified insects, Annelida, plant matter, Decapoda, Diptera-pupae, Coleoptera and Mollusca.

annelids, coleopterans, Diptera-pupae and plant matter were also consumed, but less than the other groups.

The first separation in the cluster analysis (Figure 3), branches A, B and C, occurred due to length classes. The branches $\mathrm{A}$ and $\mathrm{B}$ corresponded to individuals from length classes 3 and 4, while individuals of branch $C$ were from length classes 1 and 2 . The year seasons did not make

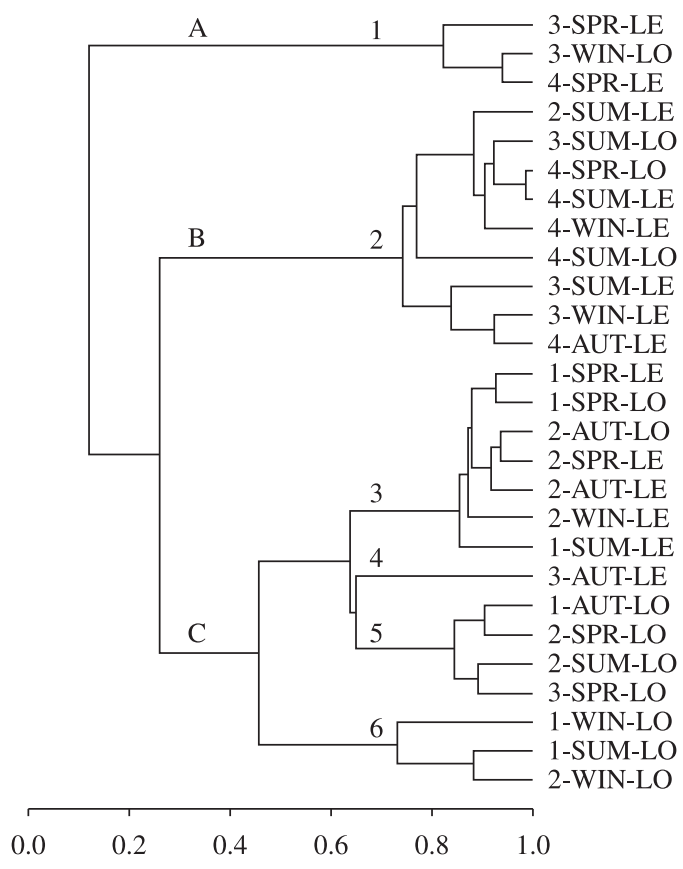

Figure 3. Cluster analysis of similarity (Bray-Curtis coefficient) considering the composition of the feeding index (IAi) among the 27 groups analysed. The groups were set according to its length class $(1: 11.4-14.3 \mathrm{~cm} ; 2: 14.4-17.3 \mathrm{~cm}$; 3: $17.4-020.3 \mathrm{~cm}$; 4: $20.4-24.9 \mathrm{~cm}$ ); year seasons (SPR: spring; SUM: summer; AUT: autumn; WIN: winter) and environment (LE: lentic; LO: lotic).

any specific separation, all the seasons were dispersed in all the branches. Concerning the spatial variations, there was separation between lentic and lotic environments just inside branch $\mathrm{C}$. This separation placed all groups from lentic environment in branches 3 and 4 and almost all groups from lotic environment in branches 5 and 6 . The food items responsible for the branches separations can be observed in Table 3. The great consumption of Odonata formed branch A1. Branch B1 was formed due to the consumption of Ephemeroptera. For groups in branch C3 Diptera was the main item. The group from branch C4 consumed Diptera and Ephemeroptera. The groups that formed branch C5 consumed Diptera and Trichoptera. The groups from the last branch, C6, consumed mainly Trichoptera.

\section{Discussion}

Pachyurus bonariensis showed high feeding activity, especially compared to piscivorous fishes: their stomachs were almost always full, in all situations. It is common for invertivorous fishes to show higher feeding activity than piscivorous ones (Lucena et al., 2000; Soares and Vazzoler, 2001; Vitule and Aranha, 2002; Braga, 2005; Fagundes et al., 2007). The variations in feeding activity among the seasons of the year are closely related to the lowest fullness degree obtained in the winter, with this season differing significantly from the others. Previous studies 
Table 3. Feeding indexes (IAi) of the 27 groups analysed in the Ibicui River. The groups were set according to its length class (1: 11.4-14.3 cm; 2: 14.4-17.3 cm; 3: 17.4-20.3 cm; 4: 20.4-24.9 cm); year seasons (SPR: spring; SUM: summer; AUT: autumn; WIN: winter) and environment (LE: lentic; LO: lotic). The mainly food items for each group were highlighted with an asterisk (*). To facilitate comparisons the groups were placed according to its position in the cluster analysis (following this order: branches A1, B2, C3, C4, C5 and C6).

\begin{tabular}{|c|c|c|c|c|}
\hline Group & Odonata & Ephemeroptera & Diptera & Trichoptera \\
\hline 3 - SPR - LE & $78.8^{*}$ & 4.7 & 14.2 & 2.3 \\
\hline 3 - WIN - LO & $93.6^{*}$ & 1.6 & 2.9 & 1.8 \\
\hline 4 - SPR - LE & $99.5^{*}$ & 0.0 & 0.5 & 0.0 \\
\hline 2 - SUM - LE & 0.1 & $82.0 *$ & 16.0 & 1.9 \\
\hline 3 - SUM - LO & 0.0 & $87.7 *$ & 2.9 & 9.4 \\
\hline 4 - SPR - LO & 0.0 & $92.4^{*}$ & 6.3 & 1.3 \\
\hline 4 - SUM - LE & 0.2 & $91.7 *$ & 5.7 & 2.5 \\
\hline 4 - WIN - LE & 8.8 & $85.9^{*}$ & 5.4 & 0.0 \\
\hline 4 - SUM - LO & 0.0 & $72.9 *$ & 0.9 & 26.2 \\
\hline 3 - SUM - LE & 7.8 & $68.3 *$ & 19.6 & 4.3 \\
\hline 3 - WIN - LE & 20.6 & $64.2 *$ & 11.6 & 3.6 \\
\hline 4 - AUT - LE & 27.2 & $65.3 *$ & 7.5 & 0.0 \\
\hline 1 - SPR - LE & 0.0 & 1.6 & $77.2 *$ & 21.3 \\
\hline 1 - SPR - LO & 0.0 & 2.6 & $83.3 *$ & 14.1 \\
\hline 2 - AUT - LO & 0.7 & 11.9 & $80.3^{*}$ & 7.1 \\
\hline 2 - SPR - LE & 1.9 & 7.9 & $78.2 *$ & 11.9 \\
\hline 2 - AUT - LE & 2.4 & 10.8 & $84.9 *$ & 1.9 \\
\hline 2 - WIN - LE & 0.0 & 14.7 & $70.6^{*}$ & 14.7 \\
\hline 1 - SUM - LE & 11.8 & 0 & $80.1^{*}$ & 8.1 \\
\hline 3 - AUT - LE & 0.0 & $49.0 *$ & $51.0 *$ & 0.1 \\
\hline 1 - AUT - LO & 0.0 & 18.2 & $44.4^{*}$ & $37.4 *$ \\
\hline 2 - SPR - LO & 1.8 & 10.8 & $52.1 *$ & $35.3 *$ \\
\hline 2 - SUM - LO & 1.3 & 24.4 & $48.7 *$ & $25.5^{*}$ \\
\hline 3 - SPR - LO & 9.0 & 24.2 & $38.2 *$ & $28.6^{*}$ \\
\hline 1 - WIN - LO & 0.0 & 2.3 & 11.5 & $86.2 *$ \\
\hline 1 - SUM - LO & 0.0 & 6.9 & 35.8 & $57.3^{*}$ \\
\hline 2 - WIN - LO & 6.5 & 7.5 & 24.0 & $62.0 *$ \\
\hline
\end{tabular}

also reported lower degrees of stomach fullness in the cold seasons (Hahn et al., 1997; Bennemann et al., 2000; Braga, 2005; Branco et al., 2005; Barreto and Aranha, 2006; Viana et al., 2006). This situation may be related to lower food availability - decrease of prey populations, less reproductive activity (Dufech and Fialho, 2006) or decreased metabolic activity of the predators (Viana et al., 2006).

Previously, the diet of $P$. bonariesis had been approached just in descriptive works of the Uruguay River, without empiric observations. However, these works did not arrive at the same conclusion about its diet. López and Castello (1968) opted for an insectivorous diet, while Devincenzi and Teague (1942) considered that aquatic plants and organic substances from the mud were the main items consumed by this fish. Recently, the diet of $P$. bonariensis has been studied with more attention by Fugi et al. (2007). These authors point to an insectivorous specialised diet, where Chironomidae and Ephemeroptera larvae were the main items consumed. In this study, aquatic insects were the mainly item found, corroborating López and Castello (1968) and Fugi et al. (2007). The main items found by Fugi et al. (2007) were also the most important ones here, however two others insect orders were also important: Odonata and Trichoptera. Pacheco et al. (2008) also found an insectivorous diet for P. schomburgkii Gunther, 1860 and P. paucirastrus Aguilera, 1983. The predominance of aquatic insects in the food of fish is common in freshwater communities (Sabino and Castro, 1990; Aranha et al., 2000; Abes et al., 2001; Andrade and Braga, 2005; Pouilly et al., 2004; Braga, 2005; Fugi et al., 2007; Pacheco et al., 2008), making the insect larvae a very important food category for fish (Zavala-Camin, 1996). Certain benthic insects, such as Diptera larvae and Ephemeroptera, are abundant in rivers with sandy bottoms (Braga, 2005) such as the Ibicuí River. 
The ontogenetic variations were confirmed as the most important for $P$. bonariensis diet. The ontogenetic pattern shown by this species in the Ibicuí River is widely observed in fish diets (Hahn et al., 1997; Abelha et al., 2001; Vitule and Aranha, 2002; Araújo et al., 2005; Rezende and Mazzoni, 2006; Fugi et al., 2007). The smaller individuals, length classes 1 and 2, preyed basically on Diptera-larvae and Trichoptera, the smallest items, and this pattern gradually changed as larger fish took larger food, Ephemeroptera and Odonata. Fugi et al. (2007) found similar patterns in $P$. bonariensis in two lakes of the Pantanal, where smaller fish preyed mostly on chironomids and larger ones preyed mostly on ephemeropterans. This pattern can be attributed to differences in energy requirements and morphological limitations (Abelha et al., 2001; Rezende and Mazzoni, 2006). Ontogenetic shifts in diet may also decrease intraspecific competition (Araújo et al., 2005).

Spatial variations also happened, but just for juveniles, length classes 1 and 2. Trichoptera was found mainly in lotic environmental and Diptera in lentic ones. Trichoptera is known to be an insect group adapted to lotic environments (Kikuchi and Uieda, 1998). The most important source of dietary variation for $P$. bonariensis was related to intrinsic biological characters of the species. However the food availability, heterogeneously distributed in the environment, was also important for this species, suggesting that this species can adapt its diet to environmental changes.

Regarding the Sciaenidae diet, marine species consume mainly decapod crustaceans (Lunardon, 1990; Vazzoler, 1991; Figueiredo and Vieira, 1998; Vendel and Chaves, 1998; Soares and Vazzoler, 2001; Branco et al., 2005). Freshwater sciaenids consume mainly fish and insects (Mourão and Torres, 1984; Hahn et al., 1997, 1999; Alvim and Peret, 2004; Bennemann et al., 2006; Fugi et al., 2007; Pacheco et al., 2008). It can be an adaptation of the species that invaded freshwater to the low availability of crustaceans and great availability of insects in comparison to marine habitats. The complete absence of fish in the diet of $P$. bonariensis, compared to other freshwater sciaenids, is likely associated with its relatively smaller body size and mouth morphology (small and sub-inferior).

Although $P$. bonariensis showed ontogenetic and spatial variations in the main items consumed, the main items were always insects and its diet was composed exclusively of invertebrates. These results corroborate Fugi et al. (2007), characterising P. bonariensis as a fish with a solely invertivorous feeding habit, mainly insectivorous, also in the Ibicuí River.

Acknowledgements - We thank Antônio José Urrutia Cohendet, Cleiton Adriano Signor, Lilian Fronza, Mariana Parizotto Almeida, Musa Nabih Musa Othman and Professor Sônia Cechin for technical and logistical assistance. We are also grateful to all those who helped to identify the food items: Camila Fagundes, Carla Kotzian, Joele Baumart, Márcia Spies and Sandro Santos. Special thanks to Professors Bernardo Baldisserotto, Marilise Krügel and Mírian Albrecht for suggestions for improvements to the manuscript and/or analyses. Janet W. Reid revised the
English text. Personal grants were provided by PET/SESu/MEC and CNPq.

\section{References}

ABELHA, MCF., AGOSTINHO, AA. and GOULART, E., 2001. Plasticidade trófica em peixes de água doce. Acta Scientiae, vol. 23 , no. 2 , p. $425-434$.

ABES, SS., AGOSTINHO, AA., OKADA, EK. and GOMES, LC., 2001. Diet of Iheringichthys labrosus (Pimelodidae, Siluriformes) in the Itaipu Reservoir, Paraná River, Brazil-Paraguay. Brazilian Archives of Biology and Technology, vol. 44, no. 1, p. 101-105.

ALBRECHT, MP. and PELLEGRINI-CARAMASCHI, E., 2003. Feeding ecology of Leporinus taeniofasciatus (Characiformes: Anostomidae) before and after installation of a hydroelectric plant in the upper rio Tocantins, Brazil. Neotropical Ichthyology, vol. 1, no. 1, p. 53-60.

ALVIM, MCC. and PERET, AC., 2004. Food resources sustaining the fish fauna in a section of the upper São Francisco river in Três Marias, MG, Brazil. Brazilian Journal of Biology, vol. 64, no. 2, p. 195-202.

ANDRADE, PM. and BRAGA, FMS., 2005. Diet and feeding of fish from Grande river, located below the Volta Grande reservoir, MG-SP. Brazilian Journal of Biology, vol. 65, no. 3, p. 377-385.

ARANHA, JMR., GOMES, JHC. and FOGAÇA, FNO., 2000. Feeding of two sympatric species of Characidium, C. lanei and C. pterostictum (Characidiinae) in a coastal stream of Atlantic Forest (Southern Brazil). Brazilian Archives of Biology and Technology, vol. 43 , no. 5 , p. 527-531.

ARAÚJO, FG., ANDRADE, CC., SANTOS, RN., SANTOS, AFGN. and SANTOS, LN., 2005. Spatial and seasonal changes in the diet of Oligosarcus hepsetus (Characiformes, Characidae) in a brazilian reservoir. Brazilian Journal of Biology, vol. 65, no. 1, p. 1-8.

BARRETO, AP. and ARANHA, JMR., 2006. Alimentação de quatro espécies de Characiformes de um riacho da Floresta Atlântica, Guaraqueçaba, Paraná, Brasil. Revista Brasileira de Zoologia, vol. 23, no. 3, p. 779-788.

BENNEMANN, ST., SHIBATTA, OA. and GARAVELLO, JC., 2000. Peixes do rio Tibagi: uma abordagem ecológica.. Londrina: UEL. $62 \mathrm{p}$.

BENNEMANN, ST., CAPRA, LG., GALVES, W. and SHIBATTA, OA., 2006. Dinâmica trófica de Plagioscion squamosissimus (Perciformes, Sciaenidae) em trechos de influência da represa Capivara (rios Paranapanema e Tibagi). Iheringia, Série Zoologia, vol. 96 , no. 1, p. 115-119.

BEHR, ER., 2005. Estrutura da comunidade e alimentação da ictiofauna piscívora do rio Ibicuí, Rio Grande do Sul, Brasil. Porto Alegre: Pontifícia Universidade Católica do Rio Grande do Sul. [Tese de Doutorado]

BRAGA, FMS., 2005. Feeding and condition factor of characidiin fish in Ribeirão Grande system, Southeastern Brazil. Acta Scientiarum. Biological Sciences, vol. 27, no.3, p. 271-276.

BRANCO, JO., LUNARDON-BRANCO, MJ. and VERANI, JR., 2005. Aspectos biológicos e pesqueiros de Paralonchurus brasiliensis Steindachner (Pisces, Sciaenidae), na Armação do Itapocoroy, Penha, Santa Catarina, Brasil. Revista Brasileira de Zoologia, vol. 22, no. 4, p. 1063-1071. 
CASATTI, L., 2001. Taxonomia do gênero sul-americano Pachyurus Agassiz, 1983 (Teleostei: Perciformes) e descrição de duas novas espécies. Comunicações do Museu de Ciência e Tecnologia da PUC-RS, vol. 14, no. 2, p. 133-178.

CASATTI, L., 2003. Family Sciaenidae. In REIS, RE., KULLANDER, SO. and FERRARIS Jr., CJ. (Orgs). Check list of freshwater fishes of South and Central America. Porto Alegre, Edipucrs. p. 599-602.

DEVINCENZI, GJ. and TEAGUE, GW., 1942. Ictiofauna del Rio Uruguay Médio. Anais do Museu de História Natural, vol. 5, no. 4, p. 1-104.

DUFECH, APS. and FIALHO, CB., 2006. Biologia populacional de Pachyurus bonariensis Steindachner, 1879 (Perciformes, Sciaenidae), uma espécie alóctone no sistema hidrográfico da laguna dos patos, Brasil. Biota Neotropica, vol. 7, no. 1, p. 91-96.

FAGUNDES, CK., BEHR, ER. and KOTZIAN, CB., 2007. Alimentação de Rhinodoras dorbignyi (Kröyer, 1855) (Siluriformes: Doradidae) no rio Ibicuí, Rio Grande do Sul, Brasil. Acta Scientiarum. Biological Sciences, vol. 29, no. 2, p. 137- 143.

FIGUEIREDO, GM. and VIEIRA, JP., 1998. Cronologia alimentar e dieta da corvina Micropogonias furnieri, no estuário da lagoa dos patos, RS, Brasil. Atlântica, vol. 20, p.55-72.

FUGI, R. and HAHN, NS., 1991. Espectro alimentar e relações morfológicas com o aparelho digestivo de três espécies de peixes comedores de fundo do rio Paraná, Brasil. Brazilian Journal of Biology, vol. 51, p. 4, p. 873-879.

FUGI, R., HAHN, NS., NOVAKOWSKI, GC. and BALASSA, GC., 2007. Ecologia alimentar da corvina, Pachyurus bonariensis (Perciformes, Sciaenidae) em duas baías do Pantanal, Mato Grosso, Brasil. Iheringia, Série Zoologia, vol. 97, no. 3, p. 343-347.

HAHN, NS., AGOSTINHO, AA. and DELARIVA, RL., 1999. Atividade alimentar da curvina Plagioscion squamosissimus (Heckel, 1840) (Perciformes, Sciaenidae) no Rio Paraná. Acta Scientiarum. Biological Sciences, vol. 21, no. 2, p. 309-314.

HAHN, NS., AGOSTINHO, AA. and GOITEIN, R., 1997b. Feeding ecology of curvina Plagioscion squamosissimus (Heckel, 1840) (Osteichthyes, Perciformes) in the Itaipu reservoir and Porto Rico Foodplain. Acta Limnologica Brasiliensia, vol. 9, p. 11-22.

KAWAKAMI, E. and VAZZOLER, G., 1980. Método gráfico e estimativa de índice alimentar aplicado ao estudo de alimentação de peixes. Boletim do Instituto Oceanográfico, vol. 29, no. 2, p. 205-207.

KIKUCHI, RM. and UIEDA, VS., 1998. Composição da comunidade de invertebrados de um ambiente lótico tropical e sua variação espacial e temporal. In NESSIMIAN, JL. and CARVALHO, AL. (Eds.). Ecologia de insetos aquáticos. Rio de Janeiro: UFRJ. p. $157-173$

LOPEZ, RB. and CASTELLO, JP., 1968. Las Corvinas del Río de la Plata (Pisces, Sciaenidae). Comunicaciones del Museo Argentino de Ciencias Naturales Bernardino Rivadavia, vol. 67, no. 1, p. 14-27.

LUCENA, FM., VASKE Jr., T., ELLISC, JR. and O'BRIENC, CM., 2000. Seasonal variation in the diets of bluefish, Pomatomus saltatrix (Pomatomidae) and striped weakfish, Cynoscion guatucupa (Sciaenidae) in Southern Brazil: implications of food partitioning. Environmental Biology of Fishes, vol. 57, no. 4, p. 423-434.

LUNARDON, MJ., 1990. Hábitos alimentares de Menticirrhus littoralis (Holdrock, 1860) (Perciformes - Sciaenidae) na Baía de
Paranaguá e adjacências, Paraná, Brasil. Braz. Brazilian Archives of Biology and Technology, vol. 33, no. 3, p. 717-725.

MAZZONI, R. and REZENDE, CF., 2003. Seasonal diet shift in a tetragonopterinae (Osteichthyes, Characidae) from the Ubatiba River, RJ, Brazil. Brazilian Journal of Biology, vol. 63, no. 1 , p. 69-74

MOURÃO, G. and TORRES, G., 1984. Espectro alimentar e atividade predatória da corvina, Pachyurus squamipinnis (Pisces, Sciaenidae) no reservatório de Três Marias, Rio São Francisco, MG. Anais do Seminário Regional de Ecologia, vol. 4, p. 295-309.

PACHECO, ACG., ALBRECHT, MP. and PELEGRINICARAMASCHI, E., 2008. Ecologia de duas espécies de Pachyurus (Perciformes: Sciaenidae) do Rio Tocantins, na região represada pela UHE Serra da Mesa, GO. Iheringia, Série Zoologia, vol. 98, no. 2, p. 270-277.

POUILLY, M., YUNOKI, T., ROSALES, C. and TORRES, L., 2004. Trophic structure of fish assemblages from Mamoré River floodplain lakes (Bolivia). Ecology of Freshwater Fish, vol. 13, no. 4 , p. $245-257$.

RAMBO, B., 1994. A fisionomia do Rio Grande do Sul. 3 ed. São Leopoldo: Unisinos. 473 p.

REZENDE, CF. and MAZZONI, R., 2006. Disponibilidade e uso de recursos alóctones por Bryconamericus microcephalus (Miranda-Ribeiro) (Actinopterygii, Characidae), no córrego Andorinha, Ilha Grande, Rio de Janeiro, Brasil. Revista Brasileira de Zoologia, vol. 23, no. 1, p. 218-222

SABINO, J. and CASTRO, RMC., 1990. Alimentação, período de atividade e distribuição espacial dos peixes de um riacho da Floresta Atlântica (Sudeste do Brasil).Brazilian Journal of Biology, vol. 50, no. 1, p. 23-36.

SOARES, LSH. and VAZZOLER, AEAM., 2001. Diel changes in food and feeding activity of Sciaenid fishes from the South-western Atlantic, Brazil. Brazilian Journal of Biology, vol. 61, no. 2, p. $197-216$.

VAZZOLER, AEAM., 1991. Síntese de conhecimento sobre a biologia da corvina Micropogonias furnieri (Desmarest, 1823), da costa do Brasil. Atlântica, vol. 13, no. 10, p. 55-74.

VENDEL, AL. and CHAVES, PTC., 1998. Alimentação de Bairdiella ronchus (Cuvier) (Perciformes, Sciaenidae) na baía de Guaratuba, Paraná, Brasil. Revista Brasileira de Zoologia, vol. 15 , no. 2, p. 297-305.

VIANA, LF., SANTOS, SL. and LIMA Jr., SE., 2006. Variação sazonal na alimentação de Pimelodella cf. gracilis (Osteichthyes, Siluriformes, Pimelodidae) no Rio Amambaí, Estado de Mato Grosso do Sul. Acta Scientiarum. Biological Sciences, vol. 28, no. 2, p. 123-128.

VITULE, JRS. and ARANHA, JMR., 2002. Ecologia alimentar do lambari, Deuterodon langei Travassos, 1957 (Characidae, Tetragonopterinae), de diferentes tamanhos em um riacho da Floresta Atlântica, Paraná (Brasil). Acta Biológica Paranaense, vol. 31 , p.137-150.

WINDELL, JT. and BOWEN, SH., 1978. Methods for study of fish diets based on analysis of stomach contents. In BAGENAL, T. (Ed.). Methods for assessment of fish production in freshwaters. Oxford: Blackwell Scientific Publications. p. 219-226.

ZAVALA-CAMIN, LA., 1996. Introdução aos estudos sobre alimentação natural em peixes. Maringá: Eduem. 129 p. 
